Uludag Univ. J. Fac. Vet. Med.

35 (2016), 1,2: 1-5

\title{
Bombus terrestris Sindirim Kanalının Bazı Bölge Mukozalarının Klasik ve Lektin Histokimyasal yapısı
}

\author{
Nazan GÖÇER ${ }^{1} \quad$ Kenan ÇINAR ${ }^{1}$
}

\begin{abstract}
Özet: Bu çalışmada 15 adet Bombus terrestris türü arıdan Proventrikulus, Krop, Ventrikulus ve İleumdan alınan örnekler materyal olarak kullanıldı. Alınan örneklere ait kesitlere UEA-I, Con-A, PNA, SBA ve WGA lektinleri uygulandi.

Yapılan incelemeler sonucunda Ventrikulus ve ileumda UEA-I reaksiyonun örtü epiteli yüzeyinde güçlü olduğu belirlendi. Kropta ise reaksiyona rastlanmadı. Ventrikulus ve ileumda örtü epiteli yüzeyi ile sitoplazmanın SBA ile çok güçlü reaksiyon verdiği gözlendi. WGA uygulaması sonucunda proventrikulusun örtü epitelinde çok güçlü reaksiyon belirlendi. PNA reaksiyonunun da proventrikulus ve krop örtü epitelinde güçlü ya da çok güçlü olduğu belirlendi. ConA uygulamasında ise krop hücre yüzeyi örtü epitelinde reaksiyon gözlenmedi.
\end{abstract}

Anahtar Kelimeler: Bombus terrestris, sindirim kanalı mukozası, lektin histokimyasal yapı.

\section{The Convertional and Lectin Histochemical Structure of Some Digestive Tract Part Mucozas of Bombus Terrestris}

\begin{abstract}
In this study, proventriculus, crop, ventriculus and ileum samples taken from 15 bees belonging to the species Bombusterrestris were used as material. UEA-I, Con-A, PNA, SBA and WGA lectins were applied to sections.

As a result of evaluation of sections to which lectin histochemistry was applied, strong UEA-I reaction was observed on the epithelial surface of ventriculus and ileum. Any reaction to UEA-I was not shown in the crop region. Very strong reaction to SBA was detected at the epithelial surface and cytoplasm of the ventriculus and ileum. Epithelial surface of proventriculus stained with WGA very strongly. Strong or very strong reaction to PNA was observed in the epithelial surface of proventriculus and crop. Cell surface of crop did not react with ConA.
\end{abstract}

Key Words: Bombus terrestris, digestive tract mucosa, lectin histochemical structure.

1 Süleyman Demirel Üniversitesi Fen Edebiyat Fakültesi Biyoloji Bölümü Doğu Yerleşkesi Çünür/ ISPARTA. nazan-gocer_92@hotmail.com 


\section{Giriş}

Zarkanatlilar, (Hymenoptera) Eklembacaklı hayvanlardan Gerçek eklembacaklılar (Euarthropoda) alt dalının Böcekler (Insecta) sinıfinın Kanatlilar (Pterygota) alt sinıfina giren bir takımıdır ${ }^{7}$. Örtü altında tozlama amacı ile kullanılan bombus arısı balarıları gibi balözü ve çiçektozu ile beslenir. Örtü altı yetiştiricilikte bombus arıları uzun dilleri iri vücutları yüksek tarlacılık kapasiteleri sayesinde kullanımları yaygind $1 \mathrm{r}^{4}$.

Bombus terrestris de uzun bir özofagusun sonunda bir bal midesi bulunur. Bal midesinin bitiminde k1sa bir proventrikulus ve uzun segmentli bir ventrikulus bulunur. Daha sonra da ileum ve rektum ile sonlanır. Diș çevre ile bağlant1lı olan tüm sistemleri astarlayan mukus seröz hücreler, goblet hücreleri, silyumlu hücreler gibi özelleşmiş ve submukozadaki serömüköz bezler tarafından üretilen viskoz yapışkan bir salg1 kompleksidir. Mukus nesnelerin geçişi için yağlama epitelin üstündeki hidratlı tabakanın korunması, patojen ve zehirli maddeler için bir bariyer oluşturur. Besin ve gaz alışverişi için geçirgen bir jel tabakası oluşturmanın yanında pek çok fonksiyonu yerine getirmektedir ${ }^{1,6}$. Mukusun \%95'i su olmak üzere musinler, tuzlar, fosfolipitler, yağ asitleri, kolesterol, lizozim, immünoglobülinler, defensinler ve büyüme faktörlerinden oluşmaktadır. Bununla birlikte en önemli bileşiği onun vizkoz ve elastik jel benzeri özelliklerinden sorumlu olan musinlerdir ${ }^{8,13,2}$. Musinler yüksek molekül ağırlıklı mukosubstans, proteoglikan veya glikoprotein olarak adlandirılan maddelerdir ${ }^{14}$.

Glikoprotein veya protein yapısında olan lektinler, hücreleri birbirine çapraz bağlayan ve çöktüren moleküllerdir. Lektinler hücrelerde ve dokularda floresan boyalar veya enzimlerle konjuge edilebilirler ${ }^{10}$.

Lektinler zardaki spesifik karbonhidratlara bağlanırlar. Con A lektini ise Mannoz ve Glukoz ile inhibe olmaktadır. WGA lektininin zar reseptörlerindeki N-Asetil-Glukozamin ve Siyalik Asit'e bağlanma özelliği bulunmaktadır. UEA-1 lektini zarlardaki $\alpha$-L-Fukoz karbohidrat birimleriyle bağlanmaktadır.PNA lektini zar reseptörlerinin $\beta$-D-Galaktoz- $(1 \rightarrow 3)-\mathrm{D}-\mathrm{N}$-Asetil -Galaktozamin birimleriyle SBA lektini zar reseptörlerinin $\alpha$ ve $\beta$-D-N-Ac-Galaktozamin birimleriyle bağlanmaktadır ${ }^{11,5}$.

$\mathrm{Bu}$ çalışmada Bombus terrestris sindirim sisteminde bulunan glikoproteinlerin lektin his- tokimyasal yapılarının Con A (Canavalia ensiformis), PNA (Arachis hypogaea), UEA-I (Ulex europaeus), SBA (Glycine max) ve WGA (Triticum vulgare) lektinleri ile belirlenmesi amaçlandi.

\section{Materyal ve Metod}

Bu çalışmada 15 adet Bombus terresetris türü arı materyal olarak kullanıldı. Canlı olarak laboratuara getirilen arilar abdomen boyunca ince uçlu makas yardımıyla disekte edildi.Stereo mikroskop altında sindirim sistemi bütün olarak çıkarıldı. Daha sonra proventrikulus, bal midesi (krop), ventrikulus ve ileum bölümlerine ayrılıp bouin solüsyonunda 16 saat fikse edilen dokular daha sonra dehidrasyon için yükselen alkol serilerinden (\%50, \%70, \%80, \%96 \%100) geçirildi ve parafin ile blokland.

Parafin bloklardan 5-6 $\mu \mathrm{m}$ kalınlığında alınan kesitlere lektin histokimya yöntemi uyguland1. $\mathrm{Bu}$ yönteme göre kesitler 10 dakika \%0.3'lük hidrojen peroksit $\left(\mathrm{H}_{2} \mathrm{O}_{2}\right)$ ile muamele edildi ve daha sonra distile su ile çalkaland. Ardından kesitler 0.1 M ve pH 7.2'lik PBS içeren \%1'lik Bovine Serum Albumine (BSA) ile yıkandı ve PBS içinde çözülmüş Tablo 1'de belirtilen Horseradish Peroksidaz-bağlayan (HRP) lektinlerle 1 saat oda sicaklığında inkübe edildi. İnkübasyon sonrasında kesitler PBS ile yıkand1. HRP lektinlerle bağlantı içeren bölgelerin tespit edilmesi için kesitler DAB (3.3'diaminobenzidine tetrahydro- chloride)'da 10 dakika oda sıcaklığında inkübe edildi. Kesitler distile su ile yıkandıktan sonra alkol ve ksilollerden geçirildi ve entellan ile kapatıldı. Hazırlanan preparatlar Olympus CX 41 tipi 1ş1k mikroskobu ile incelendi ve ilgili kısımlardan fotoğraf çekimi yapıldı.

Tablo 1. Kullanılan lektinlerin izole edildiği türler, bağlanma yerleri ve dilüsyon oranları

Table 1. Isolated species, binding sites and dilution rates of used lectins

\begin{tabular}{|l|l|l|l|}
\hline \multicolumn{1}{|c|}{ Lektin } & \multicolumn{1}{|c|}{ Tür Adı } & \multicolumn{1}{|c|}{ Bağlanma Yeri } & Dilüsyon oranları \\
\hline Con A & $\begin{array}{l}\text { Canavalia ensi- } \\
\text { formis }\end{array}$ & a-D-Man, a-D-Glc & $50 \mu \mathrm{g} / \mathrm{ml}$ \\
\hline PNA & Arachis hypogaea & $\begin{array}{l}\beta-D-G a l 1, \\
\beta-D-\text { GalNAc }\end{array}$ & $25 \mu \mathrm{g} / \mathrm{ml}$ \\
\hline UEA-1 & Ulex europaeus & a-Fuc & $25 \mu \mathrm{g} / \mathrm{ml}$ \\
\hline SBA & Glycine max & a ve $\beta$-D-N-Ac-Gal & $20 \mu \mathrm{g} / \mathrm{ml}$ \\
\hline WGA & $\begin{array}{l}\text { Triticum vulgare } \\
\text { (Sigma L3892) }\end{array}$ & $\begin{array}{l}\text { a-D- [GlcNAc] n ve } \\
\text { sialik asit }\end{array}$ & $20 \mu \mathrm{g} / \mathrm{ml}$ \\
\hline
\end{tabular}




\section{Bulgular}

Uygulanan lektin histokimyasal boyama yöntemleri sonucunda elde edilen bulgular Tablo 2'de özetlendi. UEA-I uygulamas1 sonucunda proventrikulus örtü epiteli hücrelerinin yüzeyinde orta yoğunlukta, hücrelerde ise zayıf reaksiyon gözlendi (Şekil 1a). Bal midesinde UEA-I reaksiyonuna rastlanmadı (Şekil 1b). Ventrikulus (Şekil 1c) ve ileum (Şekil 1d) epitel hücrelerinin yüzeyinde güçlü, sitoplazmada ise zayıf reaksiyon saptandi.
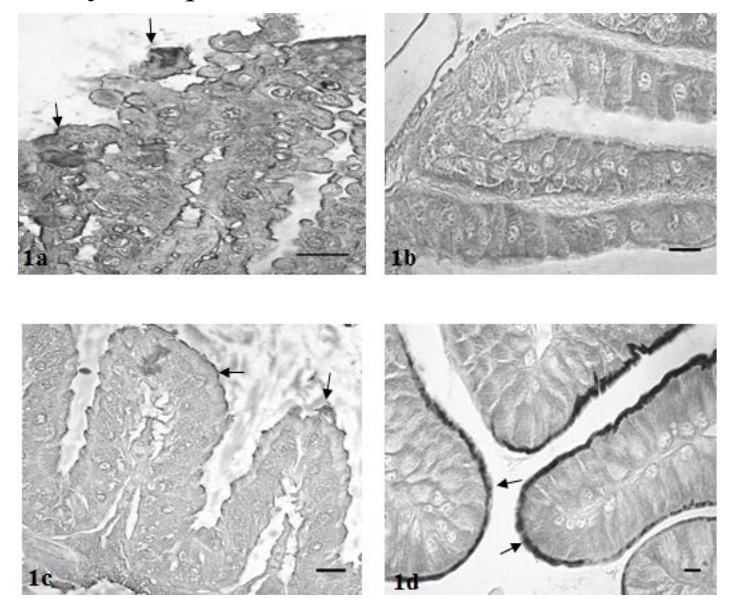

Şekil 1. UEA-I. 1a) Proventrikulus. Hücre yüzeyinde orta yoğunlukta reaksiyon (oklar), Bar: $80 \mathrm{lb}$ ) Krop. Hücre yüzeyinde negatif reaksiyon Bar: 80 $\mu m$ 1c) Ventrikulus. Hücre yüzeyinde güçlü reaksiyon (oklar), Bar: $80 \mu \mathrm{m}$ 1d) Illeum. Hücre yüzeyinde güçül reaksiyon (oklar), Bar: $50 \mu \mathrm{m}$

Figure 1. UEA-I 1a) Proventriculus. Moderate density reaction on cell surface (arrows), Bar: 80 um 1b) Krop. The negative reaction on the cell surface, Bar $80 \mu \mathrm{m}$ 1c) Ventriculus. Strong reaction on the cell surface (arrows), Bar: $80 \mu \mathrm{m}$ 1d) Ileum. Strong reaction on he cell surface (arrows),Bar:50 $\mu \mathrm{m}$

Con-A uygulamasında proventrikulus örtü epitelinin yüzeyinde zayıf reaksiyon gözlenirken (Şekil 2a) bal midesinde ise reaksiyona rastlanmadı (Şekil 2b). Ventrikulus (Şekil 2c) ve ileumda (Şekil 2d) Con-A'nın hücre yüzeyinde orta derecede reaksiyon saptand. Ventrikulusun hücre sitoplazmasında orta, ileumun hücre sitoplazmasında ise zayıf bağlanma gösterdiği belirlendi. Aynı zamanda ventrikulus örtü epiteli hücrelerinin bazaline de orta derecede bağlanma gözlendi.

PNA uygulamasi sonucunda proventrikulus (Şekil 3a) ve bal midesi (Şekil 3b) örtü epiteli hücrelerinin yüzeyinde çok güçlü, hücre sitoplazmalarında ise güçlü bağlanma olduğu gözlendi. PNA uygulamasında ventrikulus epi- telinin yüzeyinde güçlü (Şekil 3c) sitoplazmada ise orta derecede reaksiyon (Şekil 3d) saptandı.
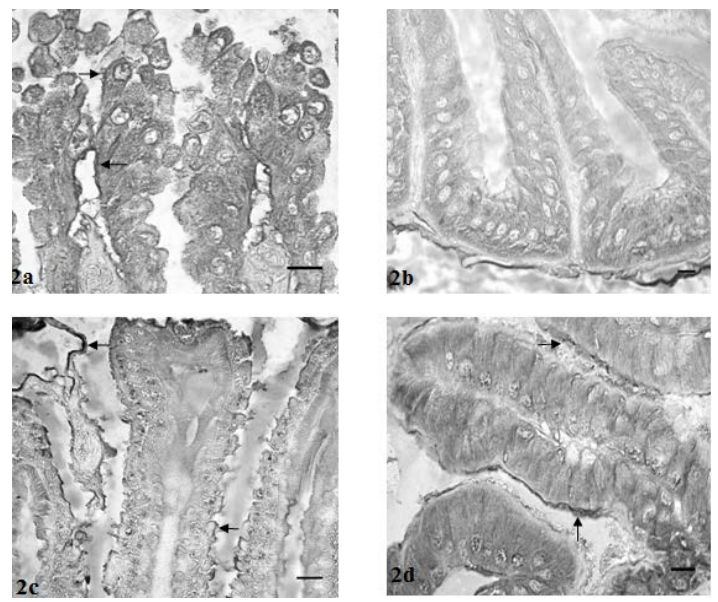

Şekil 2. Con-A. 2a) Proventrikulus. Hücre yüzeyinde

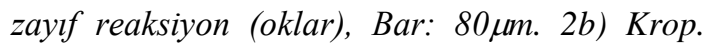
Con-A, Bar: $80 \mu m$. 2c) Ventirukuls. Hücre yüzeyinde orta yoğunlukta reaksiyon (oklar), Bar: $80 \mu m$. 2d) Illeum. Hücre yüzeyinde orta yoğnulukta reaksiyon (ok), Bar: $80 \mu m$.

Figure 2. Con-A. 2a) Proventriculus. Weak reaction on the cell surface (arrows), Bar: $80 \mu m .2 b$ ) Crop. Negative reactions on the cell surface, Bar: $80 \mu \mathrm{m} .2 \mathrm{2}$ ) Ventriculus. Moderate reaction on the cell surface (arrows). Bar: $80 \mu \mathrm{m} 2 d$ ) Ileum. Moderate reaction on the cell surface (arrows), Bar: $80 \mu \mathrm{m}$.
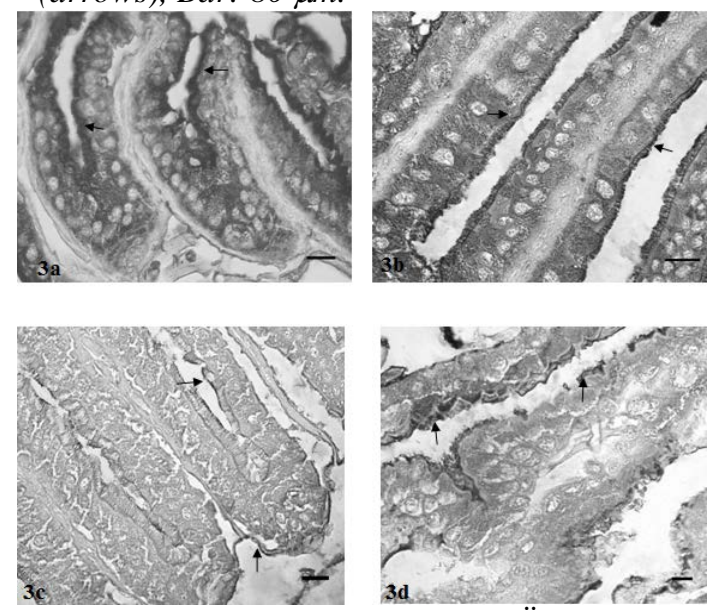

Şekil 3. PNA. 3a) Proventrikulus. Örtü epitali ve hücre yüzeyinde güçlü reaksiyon (oklar), Bar: 80 $\mu \mathrm{m}$ 3b) Krop. Örtü epiteli ve hücre yüzeyinde güçlü reaksiyon (olar), Bar: $80 \mu \mathrm{m}$ 3c) Ventrikulus. Orta yoğunlukta reaksiyon (oklar), Bar: $80 \mu \mathrm{m}$ 3d) İleum. Orta yoğunlukta reaksiyon, Bar: $50 \mu \mathrm{m}$

Figure 3. PNA. 3a) Proventriculus. Strong reaction on the epitheliae and the cell surface (arrows), Bar: $80 \mu m$. 3b) Crop. Strong reaction on the epitheliae and the cell surface (arrows), Bar 80 um. 3c) Ventriculus. Moderate reaction (arrows), Bar: $80 \mu \mathrm{m}$. 3d) Ileum. Moderate reaction (arrows), Bar: $50 \mu \mathrm{m}$ 
Proventrikulus (Șekil 4a), ventrikulus (Şekil 4b) ve ileum (Şekil 4c) örtü epiteli yüzeyinde çok güçlü, bal midesinde (Şekil 4d) ise güçlü SBA reaksiyonu gözlendi. Bu uygulama sonucunda hücre sitoplazmalarının proventrikulusta güçlü, bal midesinde ve ventrikulusta orta orta yoğunlukta, ileumda ise zayıf reaksiyona sahip oldukları saptandı.

WGA uygulaması sonucunda proventrikulus (Şekil 5a) örtü epiteli yüzeyinde çok güçlü, sitoplazmada orta yoğunlukta; bal midesi (Şekil5b) ve ileumda(Şekil 5c) örtü epiteli yüzeyinde orta yoğunlukta reaksiyon saptandi. Bal midesinde ise hücre sitoplazmasında reaksiyona rastlanmadi. Ventrikulusta örtü epiteli hücrelerinin bazalinde ise orta yoğunlukta reaksiyon belirlendi (Şekil 5d).
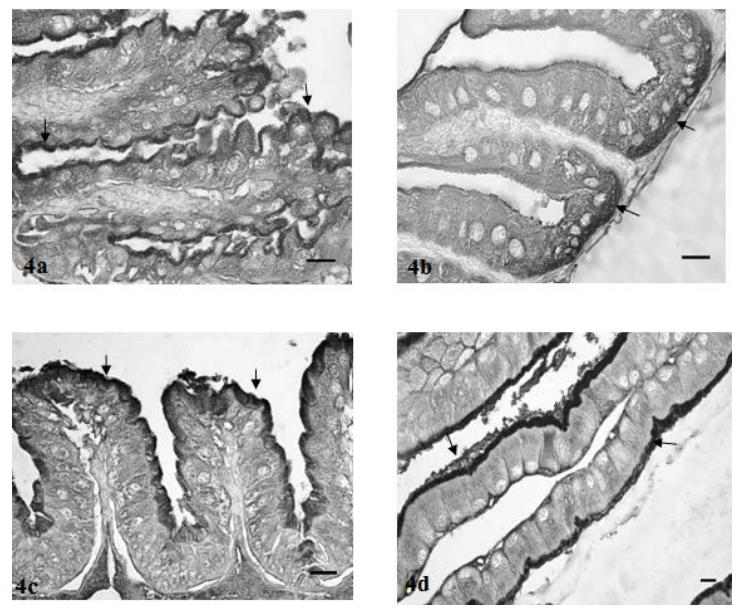

Şekil 4. SBA. 4a) Proventrikulus. Örtü epiteli ve hücre yüzeyinde güçlü reaksiyon (oklar), Bar: 80 $\mu \mathrm{m}$ 4b) Krop. Örtü epiteli ve yüzeyinde orta yoğunlukta reaksiyon (oklar), Bar: $80 \mu \mathrm{m} 4 \mathrm{c}$ ) Ventrikulus. Hücre yüzeyinde çok güçlü reaksiyon (oklar), Bar: $80 \mu m$ 4d) Illeum. Hücre yüzeyinde çok güçlü reaksiyon (oklar), Bar: 80 $\mu \mathrm{m}$.

Figure 4. SBA. 4a) Proventriculus. Strong reaction on the epitheliae and the cell surface (arrows), Bar: $80 \mu \mathrm{m} .4 \mathrm{~b}$ ) Crop. Moderate reaction on the epithelia and the cell surface (arrows), Bar: 80 $\mu \mathrm{m} .4 c$ ) Ventriculus. Very strong reaction on the cell surface (arrows), Bar: $80 \mu \mathrm{m}$. 4d) Ileum. Very strong reaction on the cell surface (arrows), Bar: $80 \mu m$.
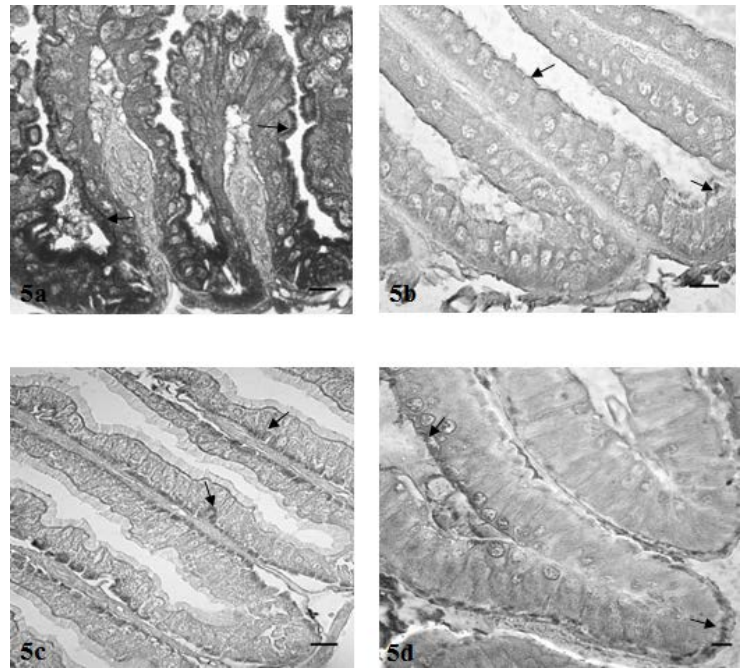

Şekil 5. WGA. 5a) Proventrikulus. Örtü epiteli yüzeyinde çok güçlü reaksiyon (oklar), Bar: $80 \mu \mathrm{m}$ 5b) Krop. Örtü epiteli yüzeyinde orta yoğunlukta reaksiyon (oklar), Bar: $80 \mu \mathrm{m}$ 5c) Ventrikulus. Hücre bazalinde orta yoğunlukta reaksiyon (oklar), Bar: $80 \mu m$ 5d) İleum. Örtü epiteli yüzeyinde orta yoğunlukta reaksiyon (oklar), Bar: $80 \mu \mathrm{m}$.

Figure 5. WGA. 5a) Proventriculus. Very strong reaction on the epithelia and the cell surface (arrows), Bar: $80 \mu m$. 5b) Crop. Moderate reaction on epitheliae surface (arrows), Bar: 80 $\mu \mathrm{m} .5 \mathrm{c}$ ) Ventriculus. Moderate reaction in basal cells (arrows), Bar: $80 \mu \mathrm{m} .5 d$ ) Ileum. Moderate reaction on epitheliae surface (arrows), Bar: 80

\section{Tartışma ve Sonuç}

Shomali Moghaddam, yaptı̆̆ı çalışmada bazı Lepidopter türlerinde bölge ayrımı yapmaksızın bağırsak epitel hücre zarlarıda WGA ve PNA lektinlerinin kuvvetli reaksiyon gösterdiği belirtmiștir. Agrotis segentum larvalarında bağırsak epitel hücre zarlarında WGA lektininin zayıf reaksiyon PNA lektininin ise orta seviyede reaksiyona rastlandığını bildirmiştir ${ }^{12}$.

Agrotis segentum larvalarının bağırsağındaki epitel hücrelerinin apikal zarlarında orta seviyede Con-A reaksiyonu olduğu bildirilmiş$\operatorname{tir}^{12}$. Bu çalışmada da Bombus terrestris bağırsağının apikal kısmında orta seviyede reaksiyon olduğu saptand.

Acyrhosiphon pisum da (fistık apidi) ConA'nın orta bağırsak epiteli hücrelerinde kuvvetli seviyede bağlanma oldugu bildirilmiştir ${ }^{9} \mathrm{Bu}$ çalışmada da Con-A'nın bazı hücre sitoplazmalarında zayıf yada negatif, hücre yüzeylerinde ise orta yoğunlukta bağlanma gösterildiği saptand. 
WGA ConA ve PNA'nın Lutzomyia longipalpis sineğinin ${ }^{3}$ bağırsak epiteline bağlanmadığı belirtilmiştir. Agrotis segentum da ise zayıf seviyede reaksiyon verdiği bildirilmiştir. Agrotis segentum larvalarında orta bağırsak apikal hücre zarında zayıf Con- A reaksiyonu olduğu bildirilmiştir $^{12}$. Bu çalışmada da PNA epitelin yüzeyinde güçlü şekilde reaksiyon saptanırken apikal hücre zarında orta seviyede Con-A reaksiyonu olduğu saptandı.

\section{Kaynaklar}

1. Allen, A., 1981. Structure and function of gastrointestinal mucus. In: Physiology of the Gastroenterology Tract. (Johnson, L., -ed.) Raven Press, pp. 617-639, New York, USA.

2. Dekker, J., Rossen, J. Büller, H., Einhard, A., 2002. The MUC Family: An Obituary. Trends in Biochemical Sciences, 27 (3), 126-31

3. Evangelista, L.G.,ve Leite, A.C.R. 2002. Histochemical localization of N- AcetylGalactosamine in the midgut of Lutzomyia longipalpis (Diptera: Psychodidae). J.Med. Entomol, 39(3), 432-439.

4. Gösterit A., 2001. Bombus terrestris Arılarında Diyapoz Sonrası Ana Arı Ağırlı̆̆ ve Değişik Beslenme Yöntemlerinin Koloni Gelişimi ve Üreme Özellikleri Üzerine Etkileri,Fen bilimleri Enstitüsü,Yüksek Lisans Tezi, 1-7, Antalya

5. Lis, H. ve Sharon, N. 2004. History of lectins: from hemagglutinins to biologicalrecognition molecules. Glycobiology vol. 14 no. 11 pp. 53R.

6. Neutra, M., Fostner, J., 1987. Gastrointestinal mucus: Synthesis, secretion and function. In:
Physiology of the gastrointestinal Tract. (Johnson, L., -ed) 2nd edn, 1Raven Press,chapter 34, Newyork.

7. Özbek H., 2002. Arılar ve Doğa. Uludağ Arı Derg, 22-25, Ağustos.

8. Phipps, R.J., 1984. Production of airway secretions. Seminars in Respiratory Medicine, 5, 314318

9. Sauvion, N., Nardon, C., Febvay, G., Gatehouse, A.M.R. and Rahbe, Y. 2004. Binding of the insecticidal lectin ConcanavalinA in pea aphid, Acyrthosiphon pisum(Harris) and induce effect on the structure of midgut epithelial cells. J Insect Physiol 50: 1137-1150.

10. Schaumburg-Lever, G., Alroy J., Ucci, A. and Lever, W. F. 1984. Distribution of carbohydrate residues in normal skin. Arch Dermatol Res 276:216-223.

11. Sharon, N., 1977. Lectins. Scientific American, 236 (6): 108-119.

12. Shomali Moghaddam N., 2008. Lectins Binding Midgut Cells of Agrotis segetum(Dennand Schiff)(Lepidoptera: Noctudidae), Ankara Üniversitesi, Fen Bilimleri Enstitüsü, Yüksek Lisans Tezi, 42 , Ankara

13. Tharton, D.J., Davies, J.R., Krayanbrink, M., Richardson, P.S., Sheehan, J.K., and Carlstedt, I., 1990. Mucus glycoproteins from "normal" human tracheobranchial secretions. Biochemical Journal, 265, 179-186

14. Yaman, K., 1999. Fizyoloji. Vipaş A.Ş., 3. Baskı, 564s. Bursa 
